
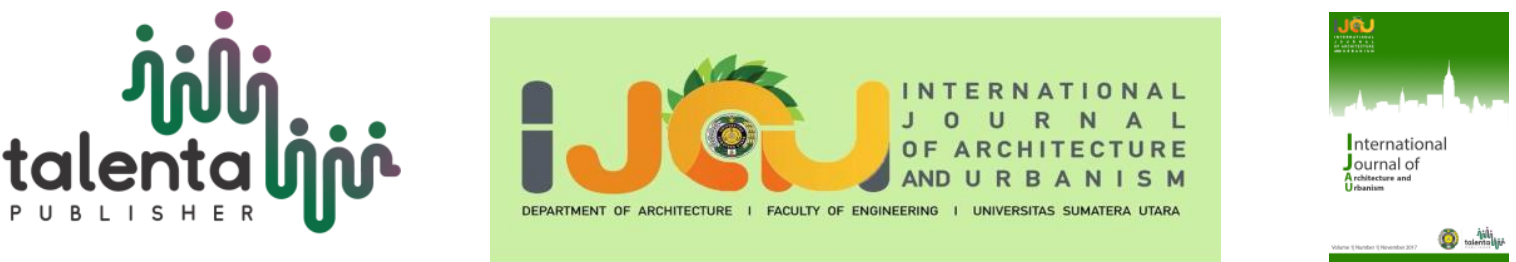

\title{
The Design of Boarding School in Simanindo, Samosir (Green Architecture)
}

\author{
Angela Fricilia Sagala ${ }^{*}$, Imam Faisal Pane ${ }^{1}$ \\ ${ }^{1}$ Department of Architecture, Faculty of Engineering, Universitas Sumatera Utara, Medan, Indonesia
}

\begin{abstract}
Simanindo is one of the priority areas that is the heart of tourist destinations on Lake Toba because of the potential for beautiful landscapes, cultural heritage, and city landmarks that show the existence of Toba Batak culture. In terms of the education sector, Simanindo residents generally complete primary and secondary education. This is because the educational infrastructure in the Simanindo sub-district is inadequate. Boarding schools can be a solution to educational problems in Simanindo District with a design concept that uses a green architectural approach to create a school that is energy efficient, safe, and environmentally friendly. The data collection method used is qualitative that collects the data and information about the condition directly from the community about the behavior observed in the region thoroughly, a field survey and then clarified with image and video documentation, as well as by collecting secondary data through studies and case study literature. Boarding School in Simanindo, Samosir Regency as an energy efficient and environmentally friendly school by maximizing the use of natural lighting and ventilation, reducing the use of chemicals, and maximizing the use of local vegetation in accordance with the context of the surrounding environment which is dominated by the function of green open spaces. This research is expected to be able to explain the application of green architecture in educational buildings that can create energy-efficient buildings and follow the cultural context in the surrounding environment.
\end{abstract}

Keyword: Boarding School, Green Architecture, Simanindo

Received 23 October 2021 | Revised 20 November 2021 | Accepted 24 November 2021

\section{Introduction}

The establishment of the Toba Caldera as a Global Geopark in July 2020 provides an opportunity for Indonesia, especially the local community, to improve the local economy. Determination of Samosir Regency as a tourist destination in the Lake Toba area will be a good opportunity if the human resources are good; otherwise, it will be a threat if the human resources are low [1]. Simanindo is one of the priority tourist areas in the Samosir Regency. Significant changes at Simanindo will occur in the economic, sociological, and social sectors [2]. When viewed from the education sector, Simanindo residents generally complete primary

\footnotetext{
*Corresponding author at: :Department of Architecture, Faculty of Engineering, Universitas Sumatera Utara, Perpustakaan Gedung $J 07$ Street, Medan 20155, Indonesia

E-mail address: angelafricilias@gmail.com
} 
and secondary education. This is due to inadequate educational facilities and infrastructure [3]. It takes commitment and exceptional attention to the education sector to improve the quality of human resources with the existence of a quality boarding school to help the government create a society that is ready to face change.

A boarding school is a school in which most or all of the students live during the part of the year that they go to lessons. The word 'boarding' is used in the sense of "bed and board," i.e., lodging and meals. Boarding school aims to foster and shape the unique character of the students. to be more independent, responsible, polite, respectful, and caring [4].

Green architecture is a design approach that seeks to increase energy efficiency, water use and reduce the use of materials that endanger human health [5]. In addition, the Green Architecture theme in the building is considered to be able to describe the function and describe the culture [6] where the project location is in a place that is thick with the culture so that the building can blend with the surrounding built environment.

Boarding schools can be a solution to educational problems in Simanindo District with a design concept that uses a green architectural approach in energy conservation to create a school that is energy efficient, safe, and environmentally friendly.

\section{Literature Review}

Boarding school has dormitory facilities where students live and study thoroughly in the school environment, and the school provides all kinds of living and learning needs. The boarding school system is strictly guarded. It is not contaminated following the education system and is protected from negative items such as cigarettes, drugs, promiscuity, etc [7]. Boarding schools are residential private schools, which means students live at school during the academic year. They resemble colleges in that students live in dorms or residence halls, but they primarily serve secondary school students. A boarding school's primary goal is to provide a learning community where students can concentrate on their studies, mature, and reach their full potential [8].

Boarding School refers to the standard of high school facilities according to the Regulation of the Minister of National Education Number 24 of 2007. A high school must have at least the following infrastructure: classrooms, library, biology laboratory, physics laboratory, chemistry laboratory, computer laboratory, language laboratory, room leadership, teacher's room, administration room, place of worship, counseling room, Health room, student organization room, toilet, warehouse, circulation room, and sports facilities [9].

The theme used in the design of the boarding school is Green Architecture. Green architecture is defined as an understanding of environmentally friendly architecture with characteristics such as 
energy-efficient lighting and equipment, water-efficient plumbing fixtures, landscapes to maximize solar energy, minimize damage to natural habitats, have alternative energy sources such as solar or wind power, non-toxic materials, local materials, and the use of recycled materials [10].

The main goal of green architecture is to be fully sustainable. Green architecture is also known as sustainable development, eco-architecture, or natural architecture [11].

Green architecture involves a combination of environmental, social, political, and technological values, which seeks to reduce the negative impact of buildings on the environment by increasing efficiency and moderation in the use of building materials, energy, and open space development [12].

It can be concluded; green architecture is an architecture that pays attention to human health and the environment by minimizing negative impacts on the environment, reducing energy use, and protecting existing natural resources.

\section{Methodology}

The data collection method used is qualitative that collects the primer data and information about the condition directly from the community in the region thoroughly, a field survey and then clarified with image and video documentation, as well as by collecting secondary data through studies and case study literature. Primary data is taken directly to the location through a field survey. Observation of the condition and condition of the location around the site is carried out to obtain valid data. The function of the survey is to obtain data in the form of site boundaries, area and shape of the site, existing land conditions, views, climatic and geographical conditions of the site, regional transportation facilities, facilities, and infrastructure of the surrounding area, and vegetation on the site. The data is then clarified with documentation in the form of photos and pictures [13].

Secondary data is obtained by collecting information sources in the research in secondary data obtained through case study literature review. Literature studies are sourced from books, regulations, and standards from relevant agencies, journals, and other literature related to design projects. Case studies are carried out by comparing cases with the same issue with the design topic regarding functions and themes taken from books, the internet, journals, scientific magazines, Etc [13].

For site selection, the Boarding School Location should be in a safe location, protected from hazards that threaten health and life safety, low traffic jams, and free from water pollution, air pollution, and noise [14]. The location should not be in a location that is too crowded and creates noise and should not be far from access to public transportation and public services. 


\section{Results and Discussion}

The project location is on Simanindo Street, which is dominated by the function of green open space. Based on the map of the Regional Spatial Plan, the planning location is in a superior zone close to a socio-cultural strategic area [15]. Simanindo Street is considered to meet the location criteria needed by residents, namely students, to study and live in areas that are safe from hazards that threaten the health and avoid pollution and noise. The project site area was measured using a satellite map with a land area of \pm 2.8 Hectares (Figure 1).

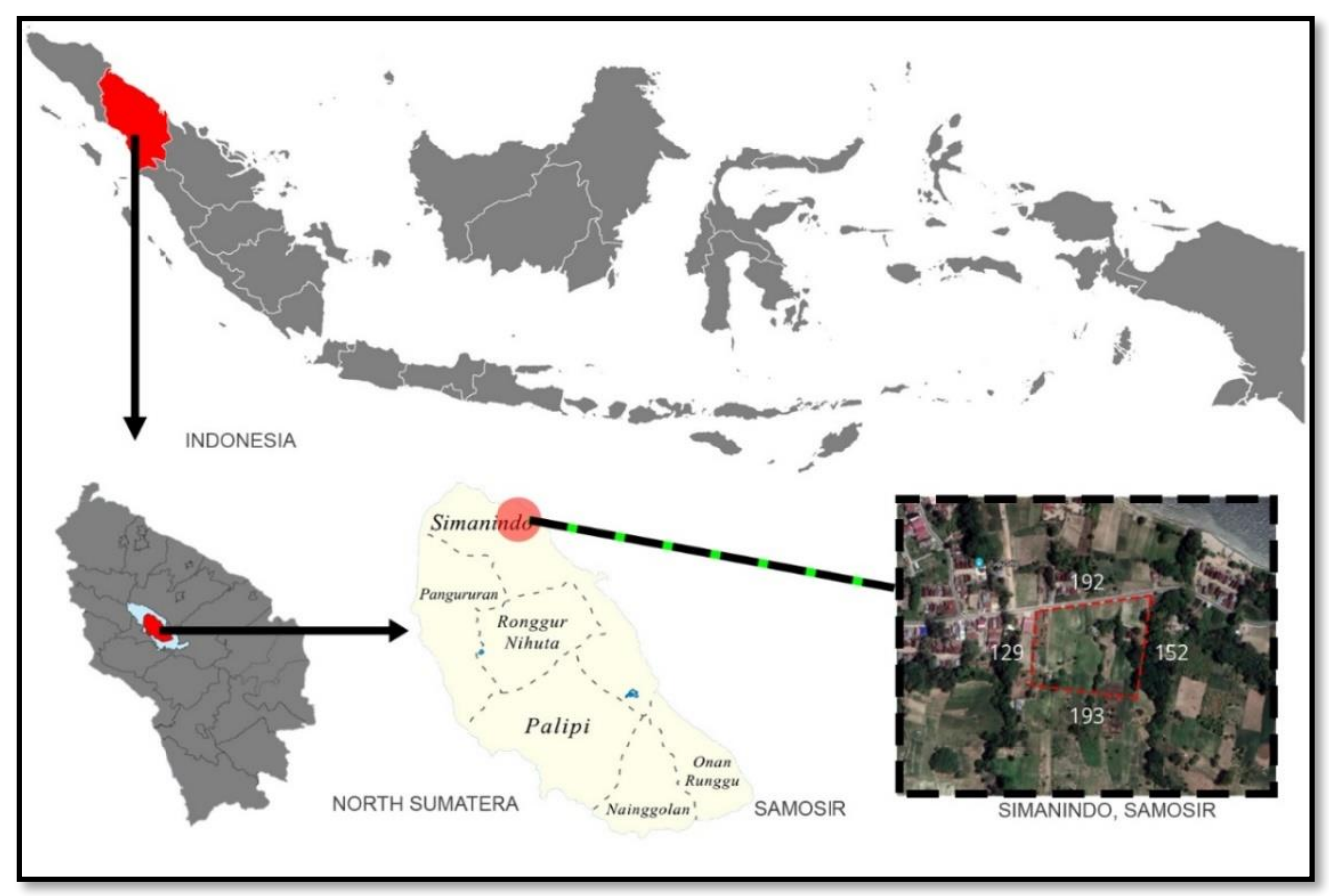

Figure 1 Project Location

\subsection{Site Potential}

The project site has one main entrance, namely from Simanindo Street, and a secondary road located west of the site. The road to the location can be passed quickly by vehicles with a road width of $\pm 6 \mathrm{~m}$. There is also a particular pedestrian path around the site with a distance of \pm 1.5 $\mathrm{m}$. Noise comes from the main road to the site, namely Simanindo Street with moderate noise. The secondary road to the west of the site is only passed by residents who have homes and work around the site so that the noise from this road is relatively low. Pollution at the design location is very low because the function around the site is dominated by Green Open Space, Rice Fields, and Plantations which can be used as air filters (Figure 2). 


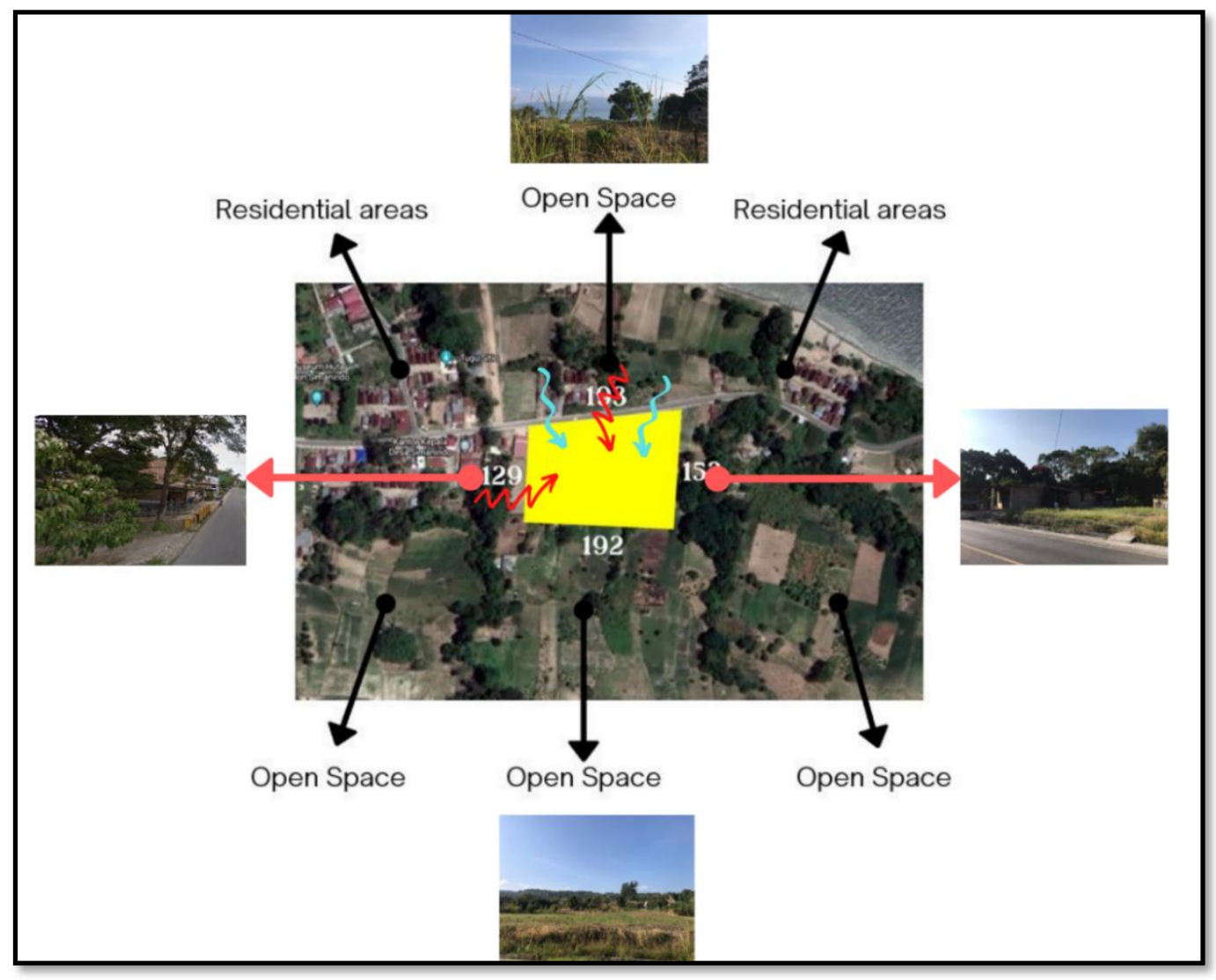

Figure 2 Site Potential

\subsection{Building Mass Concept}

There are four masses to be arranged on the site. According to the zoning division, the masses are arranged, namely schools, school facilities, and dormitory buildings that are distinguished between female and male dormitories. The additive transformation is adjusted to the amount of space required, namely a 2 -story school and a 3-story dormitory building, then given a subtractive shape transformation in the middle of the school and dormitory to place the inner court in order to maximize natural lighting (Figure 3).

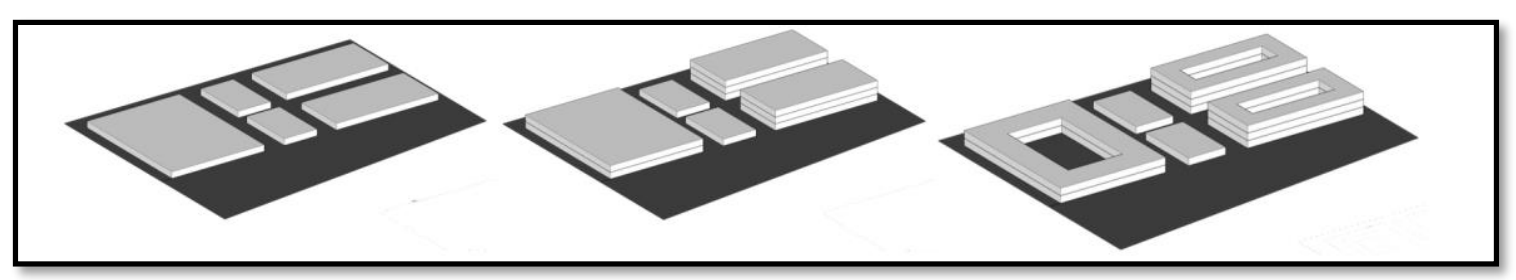

Figure 3 Building Mass Concept

\subsection{Outdoor Layout}

Outdoor space is divided by function, namely public, school, school facilities (sports), and dormitories. Public functions are placed at the very front, close to the main road, for easy access. There is a parking area and a public garden at the front. The functions of schools and 
dormitories are then connected to school facilities such as canteens, sports halls, and sports fields (Figure 4).

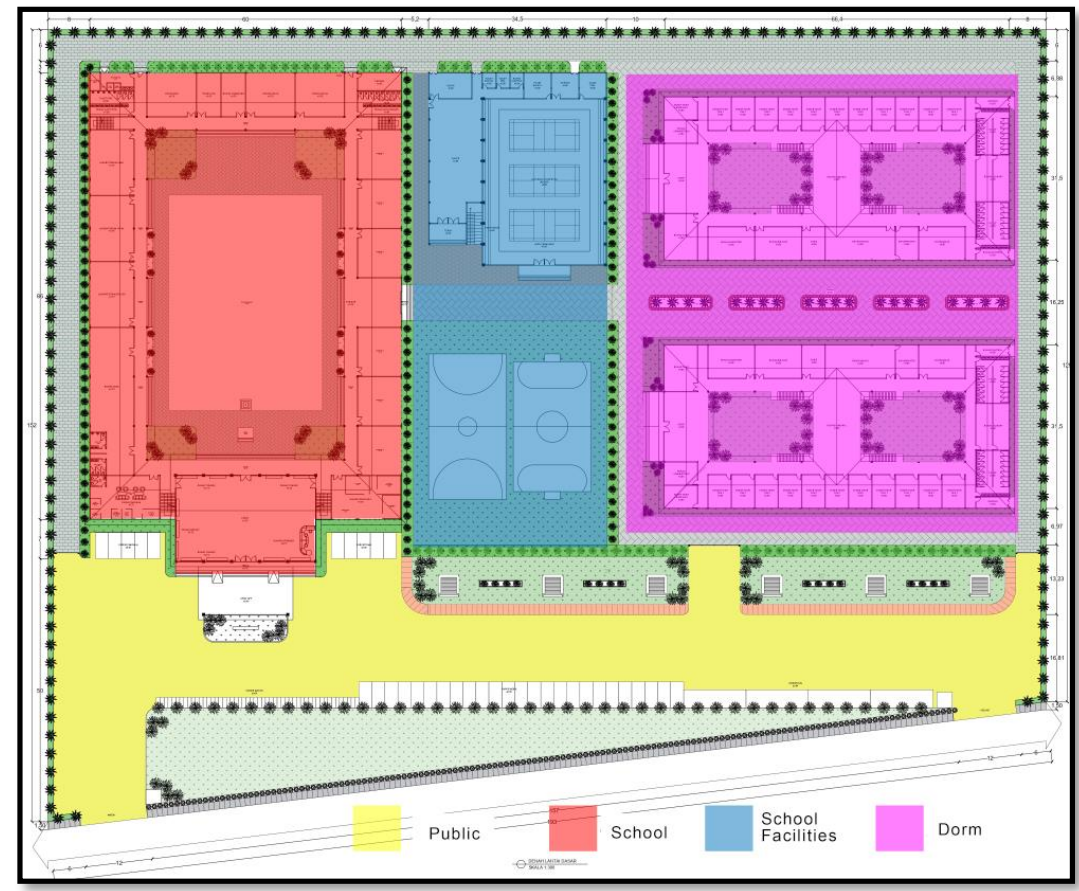

Figure 4 Outdoor Layout

\subsection{Indoor Layout}

On the 1st floor of the school, public functions are placed at the very front, namely the lobby/hall, which contains an information room, waiting room, and a school award display room. The lobby function connects the administrative, administrative, and financial rooms on the right, with the leadership and teacher rooms on the left. There is a science laboratory function adjacent to the teacher's room, namely chemistry, physics, and biology, on the 1st floor for emergency evacuation purposes. Then, there is a language lab; the School Health Services room is next to the counseling room. Service areas such as warehouses and control rooms are located at the far right and left. In the middle of the school, there is a garden and a ceremonial field with an orientation to the north. There is access to school and dormitory facilities.

There are four accesses to the second floor, namely at the front on the right and left of the lobby, then there are two at the back end right and left. At the very front of the 2nd floor, there is a semi-public function, namely the hall. On the right and left of the hall are a prayer room and student organization activities. At the back, there is a function of the library room and computer lab (Figure 5). 


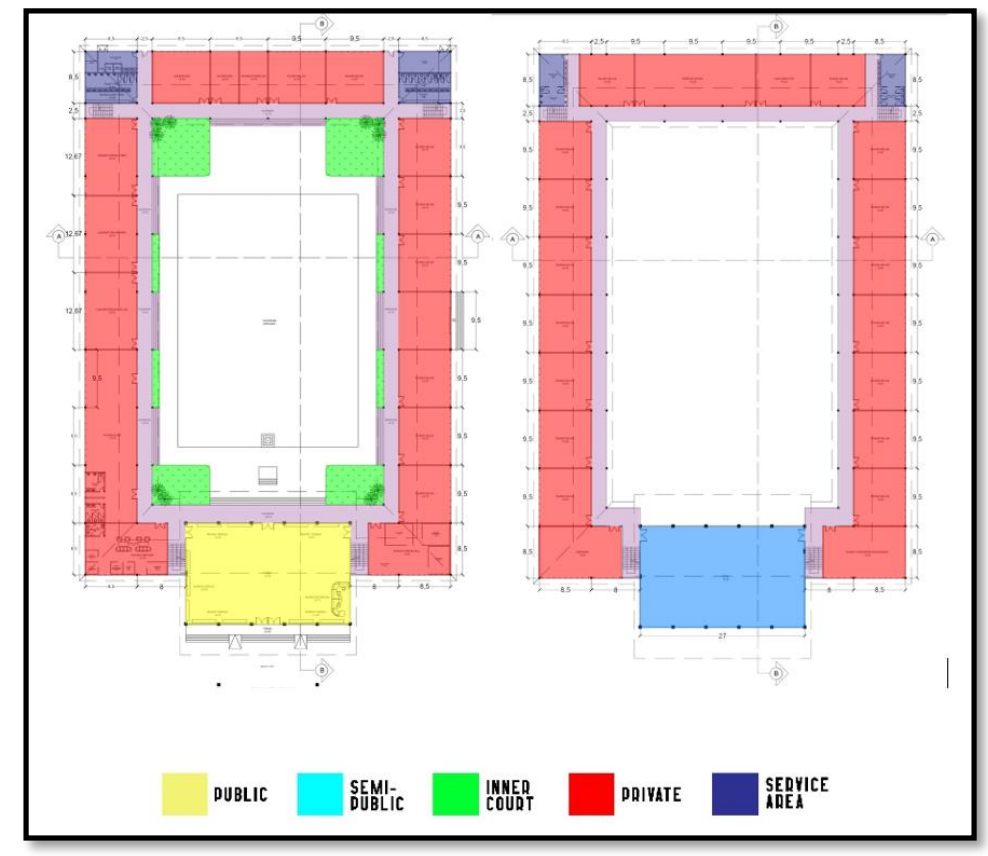

Figure 5 School Layout

The 1st floor of the dormitory contains public functions, administration, dormitory facilities, and several type 1 rooms. At the very front of the dormitory is a public area, namely the lobby and living room. There is an administrative room for storing goods or keys. Then next to the administration room, there is a manager's room facilitated by an inside toilet. On the left side, there are dormitory facilities, namely a computer room, a study room where they study, a mini library, then there is a dining room and kitchen. There is a laundry room which contains a washing machine and a drying room behind it. On the right is a type 1 bedroom. Private and semi-public functions are connected by a communal space and a garden in the middle. Service areas such as control rooms, warehouses, and toilets are on the right and left rear. Toilets are divided into two, namely shower cubicles and WC.

There is a staircase leading to the 2 nd floor in the middle of the building. Type 1 rooms dominate the 2nd floor. At the very front of the building is a semi-public function, namely outdoor and indoor communal spaces. The service area is also the same as the 1 st floor at the left and right ends. There are also laundry rooms on both the right and left sides. On the 3rd floor of the dormitory, type 2 rooms are dominated. This area is exceptional for senior students to make it calm. There is a communal rung in the middle of the building and outdoor and indoor communal spaces at the front (Figure 6). 


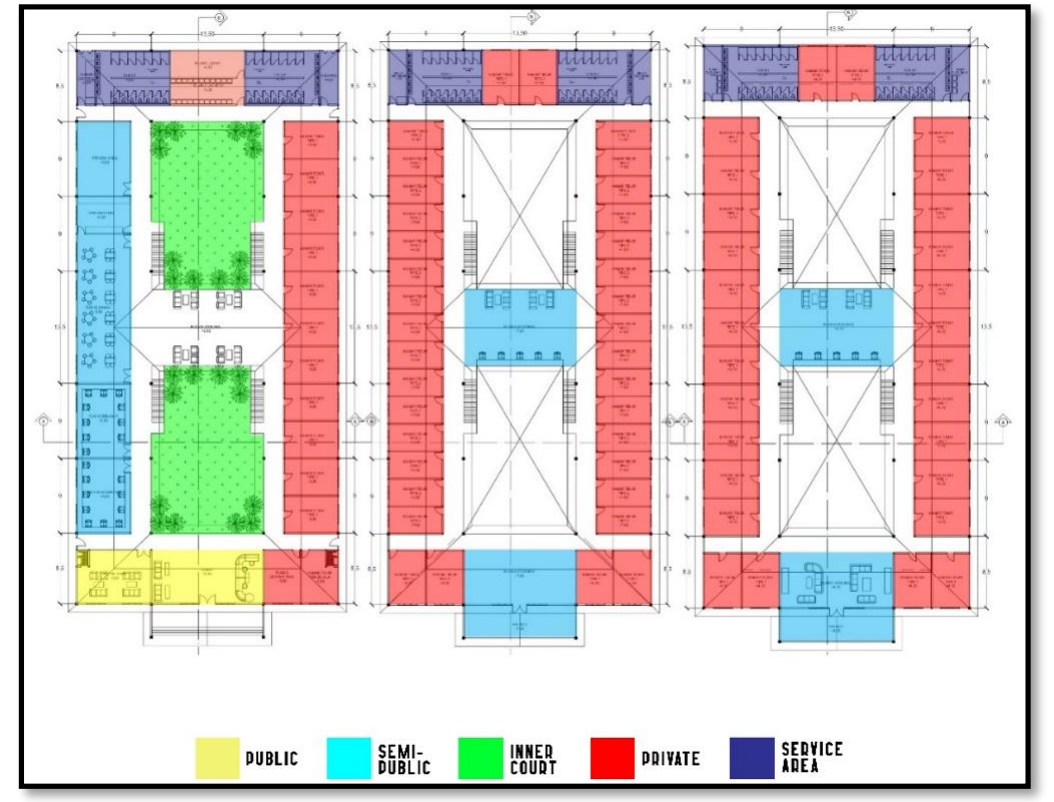

Figure 6 Dorm Layout

The Boarding School offers facilities, namely a canteen, a music room, and an indoor badminton court. The canteen is located on the right of the indoor court building. Students take food in the food serving area in front of the kitchen, then choose a seat in the area provided. Then in the front area with separate access, there are stairs to the music practice room. Furthermore, on the right, there is an indoor badminton court building. According to Regulation of The Minister of Youth and Sport of The Republic of Indonesia Number 0445 of 2014 Concerning Standards of Sports Infrastructure in The Form of Sports Building, The Type C Sports Field Building has three badmintons for local training/matches courts. The game area is 30 meters long and 20 meters wide. The length of the building is 40 meters, and the width is 30 meters. There are sitting areas to the right and left of the building. Service areas such as toilets, changing rooms, warehouses and control rooms are located at the rear of the building (Figure 7).

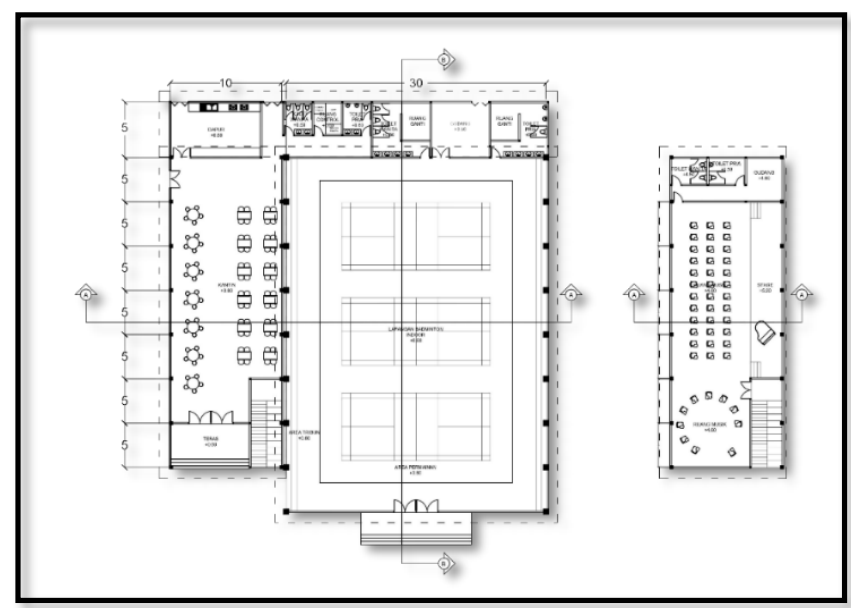

Figure 7 Indoor Sport Field Layout 


\subsection{The Application of Green Architecture}

The basic design concept refers to the Green Architecture approach [13]:

The orientation of the main building leads to the main road, which is in the north. There is anopen space in the middle of the building to maximize natural lighting from all sides of the building. Minimize the spread of solar radiation by planting shade trees and secondary skin on the east and west of the building. There is the planting of shade trees, noise-blocking plants, and dust filter plants. The vegetation used is vegetation that is easily obtained at the location, namely Ketapang, pine, Tanjong trees, and palms. Rainwater captured in the site area through the garden and the use of grass blocks which can absorb water and heat better than paving blocks (Figure 8).

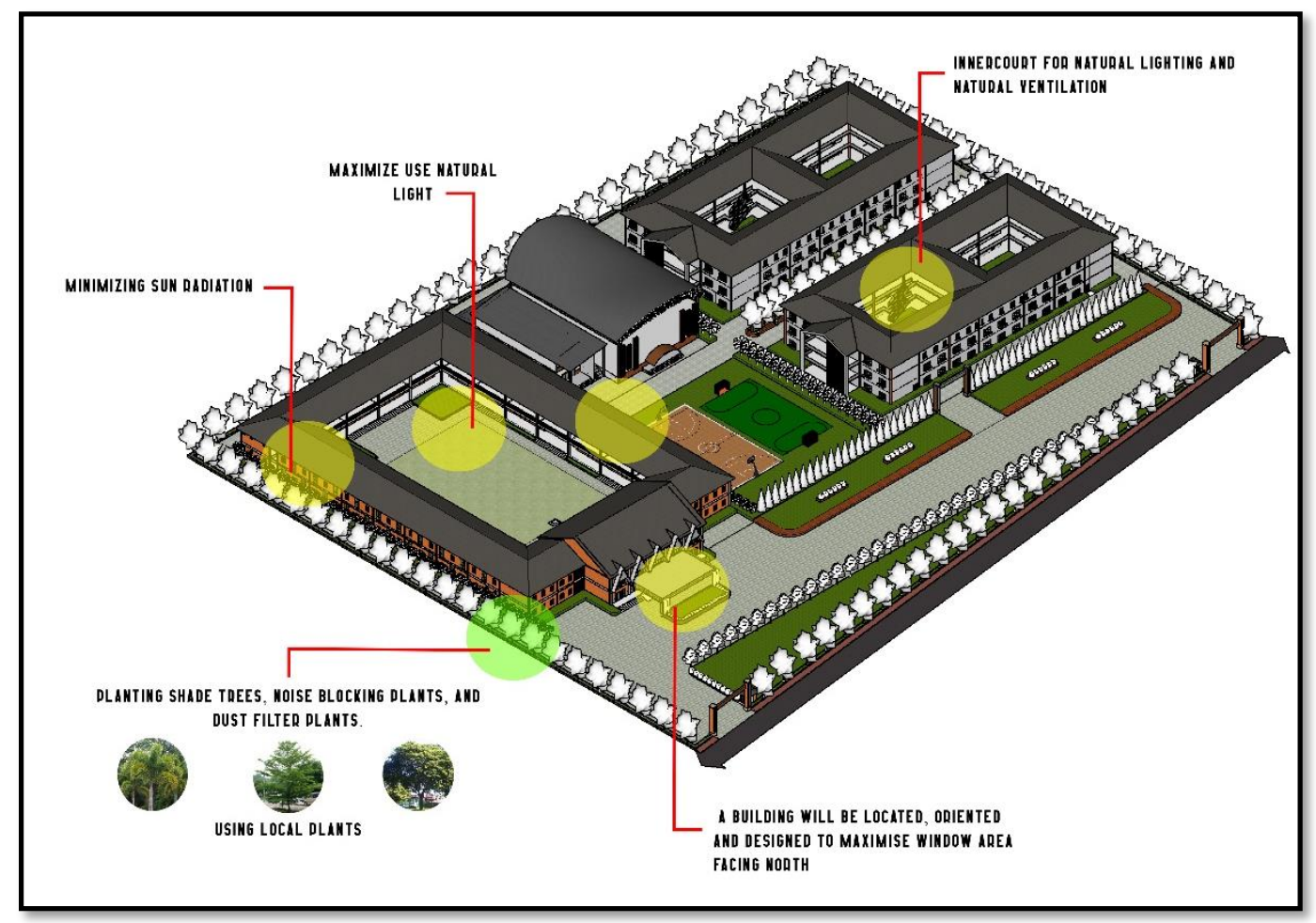

Figure 8 Site Arrangement

The comparison value of transparent building envelope with massive building envelope (window to wall ratio) is less than $30 \%$. The use of building envelope materials supports energy efficiency. Maximize the use of natural light through windows and clerestory on the side of the room close to the corridor to maximize the entry of light from both sides of the room. The provision of openings in the room supports cross ventilation in the building to reduce the heat caused by solar radiation (Figure 9). 

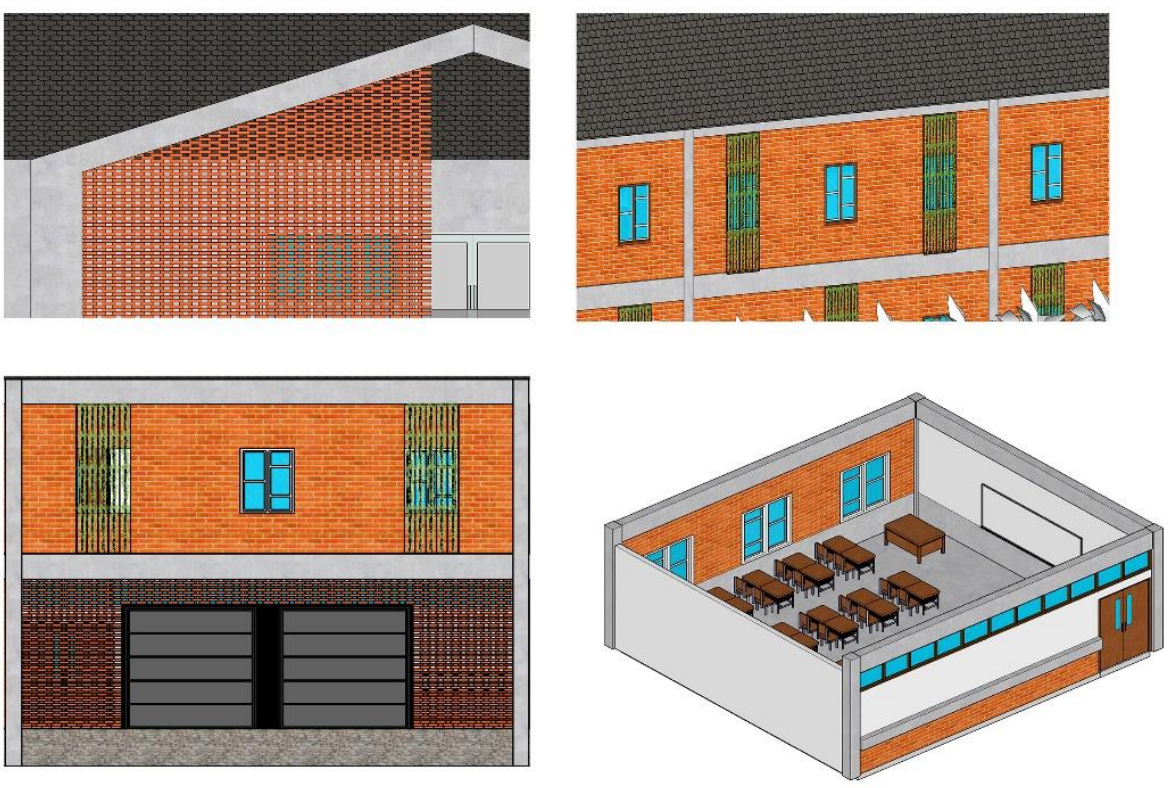

Figure 9 Natural lighting and ventilation through clerestory, windows, and non-massive walls.

There is the use of roster walls for ventilation and ventilation systems and natural lighting. Furthermore, for the selection of materials, exposed brick and exposed concrete in school buildings can reduce the use of chemicals and reduce construction costs. The bricks are then coated with a coating to reduce damage to the bricks. A building with an exposed style like this also seems to blend with nature in accordance with the context of the surrounding environment, which is dominated by the function of green open space. The facade of the building is also given wall plants to give an organic impression (Figure10).

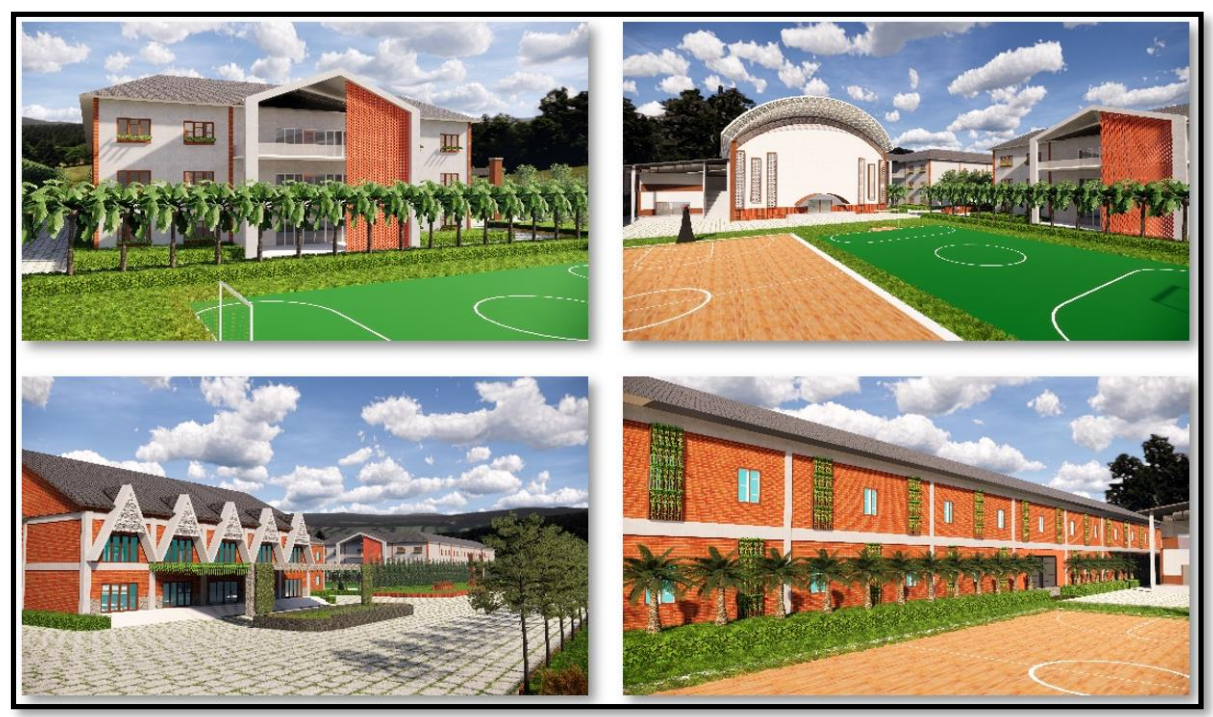

Figure 10 Exterior 


\section{Conclusion}

The design of the Boarding School, which is located in Simanindo District, Samosir, is designed to help the government create people who are ready to face changes since the establishment of the Toba Caldera as a Global Geopark by UNESCO. The project location is on Simanindo Street that is considered to meet the location criteria needed by residents, namely participants, to learn and live in safe areas from the danger that threatens their health and avoid pollution and noise. The land area of the design is $+/-2.8$ Hectares, with the surrounding function dominated by the function of open green space.

The purpose of designing a boarding school in Simanindo, Samosir Regency is to plan a boarding school design that pays attention to its relationship with the surrounding environment, plans a good relationship between schools and dormitories, and applies the Green Architecture theme by maximizing the use of natural lighting and ventilation, reducing the use of chemicals, and maximizing the use of local vegetation by the context of the surrounding environment which is dominated by the function of green open space.

From the conclusions presented, suggestions or input are needed so that the design is more developed. These suggestions are related to themes that should be further clarified and strengthened in order to create schools that are energy-efficient, safe, environmentally friendly, and in the context of the surrounding environment.

\section{Acknowledgment}

This article is written by the researcher personally as a graduation requirement and as a contribution to the government to improve the human resources of the Simanindo area by using local wisdom and preserving nature with environmentally friendly designs. The author would also like to thank the Department of Architecture, Faculty of Engineering, University of North Sumatra, and all parties who have assisted in the research and design of the Boarding School in Simanindo, Samosir Regency, with the Green Architecture Approach.

\section{REFERENCES}

[1] K. L. N. R. Indonesia, "Kaldera Toba Di Tetapkan Sebagai Unesco Global Geopark," [Online]. Available: https://kemlu.go.id/portal/id/read/1457/berita/kaldera-toba-ditetapkan-sebagai-unesco-global-geopark. [Accessed 10 March 2021].

[2] Dinas Kebudayaan \& Pariwisata , "Simanindo," 2020. [Online]. Available: Disbudpar.sumutprov.go.id. . [Accessed 10 March 2021].

[3] Badan Pusat Statistik Kabupaten Samosir, "Kabupaten Samosir dalam Angka," 2020. [Online]. Available: Samosirkab.bps.go.id. [Accessed 10 March 2021]. 
[4] S. Laiser, "The influence of boarding school to young children: A case of two boarding schools in Hai District in Kilimanjaro, Tanzania," International Journal of Education and Research, vol. 4, p. 73, 2016.

[5] O. Attmann, Green architecture, New York: McGraw-Hill, 2010.

[6] I. F. Pane and M. F. Nasution, "The Design of The Tuk-Tuk Lakeside Resort Lake Toba (Green Architecture)," International Journal of Architecture and Urbanism, vol. 4, 2020.

[7] S. Al Idrus, "Modern Pesantren (Islamic Boarding School): Competitive Advantages in Darul Yatama Wal-Masakin (Dayama) Islamic Boarding School in Jerowaru East Lombok," PALAPA, vol. 8, pp. 97-112, 2020.

[8] Marine Military Academy, "Boarding School 101: What is Boarding School?," 2020. [Online]. Available: https://www.mma-tx.org/blog/13362/boarding-school-101-what-isboarding-school/. [Accessed 10 March 2021].

[9] Kementerian Pendidikan dan Kebudayaan, "Peraturan Menteri Pendidikan dan Kebudayaan No. 24 Tahun 2007," [Online]. Available: http://repositori.kemdikbud.go.id/18715/1/Permendiknas-No.-24-tahun-2007.pdf. [Accessed 10 March 2021].

[10] B. Tasc1, "“Sustainability" Education by Sustainable School Design," Procedia Social and Behavioral Sciences, pp. 868-873, 2015.

[11] A. Ragheb, H. El-Shimy and G. Ragheb, "Green Architecture: A Concept of Sustainability," Procedia - Social and Behavioral Sciences, vol. 216, pp. 778-787, 2016.

[12] O. Joshua, "Green Building: Imperative Panacea for Environmental Sustainability and Life Cycle Construction in Nigeria," World Journal of Research and Review (WJRR), vol. 7, no. 3, pp. 15-29, 2018.

[13] F. Rahmawati [Online]. Available: http://repo.iaintulungagung.ac.id/12039/6/BAB\%20III.pdf. [Accessed 10 March 2021].

[14] Kementerian Pendidikan dan Kebudayaan Republik Indonesia, "Peraturan Menteri Pendidikan dan Kebudayaan Republik Indonesia No.7 Tahun 2020," [Online]. Available: https://jdih.kemdikbud.go.id/arsip/Salinan\%20PERMENDIKBUD\%207\%20TAHUN\%2 02020\%20FIX.pdf. [Accessed 10 March 2021].

[15] DPRD Kabupaten Samosir dan Bupati Samosir, "Peraturan Daerah (PERDA) tentang TATA RUANG WILAYAH KABUPATEN SAMOSIR TAHUN 2018-2038," [Online]. Available: https://peraturan.bpk.go.id/Home/Details/135615/perda-kab-samosir-no-3tahun-2018. [Accessed 10 March 2021]. 